\title{
Salt-marsh evolution at Northwick and Aust warths, Severn Estuary, UK: a case of constrained autocyclicity
}

\author{
J. R. L. Allen ${ }^{1}$ AND S. K. HasletT ${ }^{2 *}$ \\ 1. School of Archaeology, Geography and Environmental Sciences, University of Reading, Whiteknights, \\ Reading RG6 6AB, UK \\ 2. Coastal Research Group, University of Wales, King Edward VII Avenue, Cathays Park, Cardiff, CF10 3NS, UK \\ *Corresponding author: <s.haslett@wales.ac.uk>
}

Received 07 October 2013 g accepted 26 November 2013

\begin{abstract}
Historic maps, remote imagery and field surveys reveal that a terraced sequence of four salt marshes has arisen on a decadal-centennial time-scale over a frontage of about $4 \mathrm{~km}$ at Northwick and Aust warths exposed to westerly to northerly winds on the east bank of the Severn Estuary, UK. Except for the youngest marsh, at present very immature, each marsh built up through differential sedimentation from a mudflat until the outer zone reached a critical steepness; at that point wave-attack caused erosion that led to the rapid landward retreat of a bold, laterally extensive, marsh-edge cliff. This observed behaviour is consistent with previous models of autocyclic marshes, but evidence suggests that the extrinsic factor of medium-scale changes in wind-wave climate constrained the particular timing of marsh responses.
\end{abstract}

\section{RÉSUMÉ}

Selon les cartes historiques, les images satellites et les études sur le terrain, une suite de quatre marais salés sélevant en étages est apparue à une échelle de temps décennale et centennale. Ces marais sétendent sur environ $4 \mathrm{~km}$ entre Northwick et Aust warths, au Royaume-Uni, et sont exposés à des vents de l'ouest, du nord-ouest et du nord sur la rive est de l'estuaire de la Severn. À l'exception du marais le plus récent, qui se trouve actuellement à un stade de développement très peu avancé, chacun de ces marais sest formé grâce à la sédimentation différentielle d'une vasière. Leur périmètre latéral consiste en une falaise abrupte que l'érosion des vagues a rapidement fait reculer vers le continent. L'évolution observée concorde avec les anciens modèles de fonctionnement autocyclique des marais, mais des signes tendent à indiquer que le facteur extrinsèque du changement à moyenne échelle des conditions liées à la mer du vent a restreint le développement de ces systèmes.

[Traduit par la redaction] 


\section{INTRODUCTION}

In this paper we describe a case history that adds substantially to the growing body of empirical support for models of autocyclicity in salt marshes and their genetically linked intertidal flats. We consider autocyclicity (i.e., cycles due to local/intrinsic factors; e.g., Cecil 2003) to be a fundamental process of salt-marsh morphodynamics, until recently neglected in terms of quantitative theoretical approaches and systematic field studies (see Fagherazzi et al. 2012 for a synthesis of salt marsh models). Salt marshes are among the commonest high-intertidal environments on the low-lying coasts of northwestern Europe and eastern North America (Allen 2000), with many implications for human activities.

It has long been known that many salt marshes associated with mudflats take the form of a sequence of terrace-like morphostratigraphic units with formerly eroding scarps between, which descend stair-like toward the sea (Luternauer et al. 1995; Allen 2000; and Friedrichs and Perry 2001 provided reviews; see also Carey and Oliver 1918; Harmsworth and Long 1986; Pye 1995; Temmerman et al. 2004; Ollerhead et al. 2006; Pedersen and Bartholdy 2007). Almost a century has passed since Yapp et al. (1917), from field observations, proposed an important and stillvalid conceptual model for the formation of such salt marshes in sheltered estuaries uninfluenced by wandering tidal channels (similar to Pringle 1995). According to Yapp et al. (1917), the trapping and binding action of zoned marsh halophytes causes a marsh-platform to build up faster than the adjoining mudflat, with the result that a substantial elevation difference and sloping transitional zone develops between them. The transitional zone, as it steepens, becomes increasingly susceptible to wave-attack and evolves into an eroding and landward-retreating scarp. New marsh can form on the mudflat below the cliff and in its turn builds up against the cliff to an unstable height and outer slope, leading to another repetition of the cycle, and so on. A very similar model was proposed by Pedersen and Bartholdy (2007) for the exposed marshes adjoining sandflats in the Danish Wadden Sea. Similar cyclic development has also been noted for salt marshes in the Bay of Fundy in Atlantic Canada (e.g., Ollerhead et al. 2006).

Only within the past 20 years have the dynamics of this previously neglected process been explored quantitatively. The strongly empirical, time-stepping model described by Gao and Collins (1997) is for a particular marsh coupled with a sandflat. Depending on the relative vertical accretion rate between the sandflat and the marsh, the effect of breaking waves on the increasingly steep, sloping zone that develops between the two environments was shown to lead to scarp formation and retreat (see also Tonelli et al. 2010). Gao and Collins (1997) suggested, but did not model, how a new marsh could develop on the sandflat below the cliff. The exploratory model proposed by van de Koppel et al. (2005) emphasized the role of positive feedback in the biodynamics of a coupled mudflat-marsh. The plant-covered transitional zone becomes increasingly steep as the marsh-platform grows in elevation relative to the mudflat. Eventually the transitional zone reaches a critical steepness, at which time the authors argued that an irreversible vegetation collapse becomes possible (see also Feagin et al. 2009; Mariotti and Fagherazzi 2010). An external event such as a storm may then trigger sediment erosion, followed by scarp development (Allen 1989) and rapid retreat. A new marsh may be initiated on the mudflat provided that some of the preceding marsh with viable plants survives at the scarp foot. Mariotti and Fagherazzi (2013) and Fagherazzi et al. (2013) studied salt marshes along the US Atlantic coast and provide evidence that sediment starvation also promotes the initiation of salt marsh erosion.

These models call for empirical tests. That of Gao and Collins (1997) is site-specific, and it is therefore hardly surprising that the results are consistent with their field data from microtidal Christchurch Harbour on the English Channel coast. Two field cases from the just-macrotidal Wadden Sea and Westerschelde were advanced by van de Koppel et al. (2005) in support of their model, and van der Wal et al. (2008) and Callaghan et al. (2010) added another example from the Westerschelde. In reviewing salt marsh autocyclicity, Chauhan (2009) provided information for the Moricambe Basin of the Solway Firth in the northwest UK. The muddy, hypertidal Severn Estuary is the location of the present case history. Our account of the salt marshes and associated mudflat is based on a variety of historical sources, together with recent field surveys.

\section{SETTING}

The active salt marshes known as Northwick and Aust warths and the associated mudflat of Northwick Oaze British National Grid Reference (NGR) ST 5486-5689 - lie on the southeastern bank of the Severn Estuary (Figs. 1a, 1b). Descriptions of these marshes and their botanical character can be found in Smith (1979), Allen and Rae (1987), Haslett et al. (1998), Strawbridge et al. (2000), Dark and Allen (2005a), Haslett (2006, 2008), and Allen and Haslett (in press). The marshes are anchored to the northeast by the rock cliff and intertidal ledges at Aust (Aust Rock, Great Ulverstone, Upper Bench) and to the southwest, at Severn Beach, by a large intertidal rock-platform (English Stones) and a slightly elevated promontory. The extreme tidal range at Avonmouth, about $10 \mathrm{~km}$ downstream, is estimated at 14.8 m between 1987 and 2003 (United Kingdom Hydrographic Office 2008); it has been expanding at a rate comparable to the rate of global sea-level rise for at least several decades (Woodworth et al. 1991). As plotted in detail by Allen and 


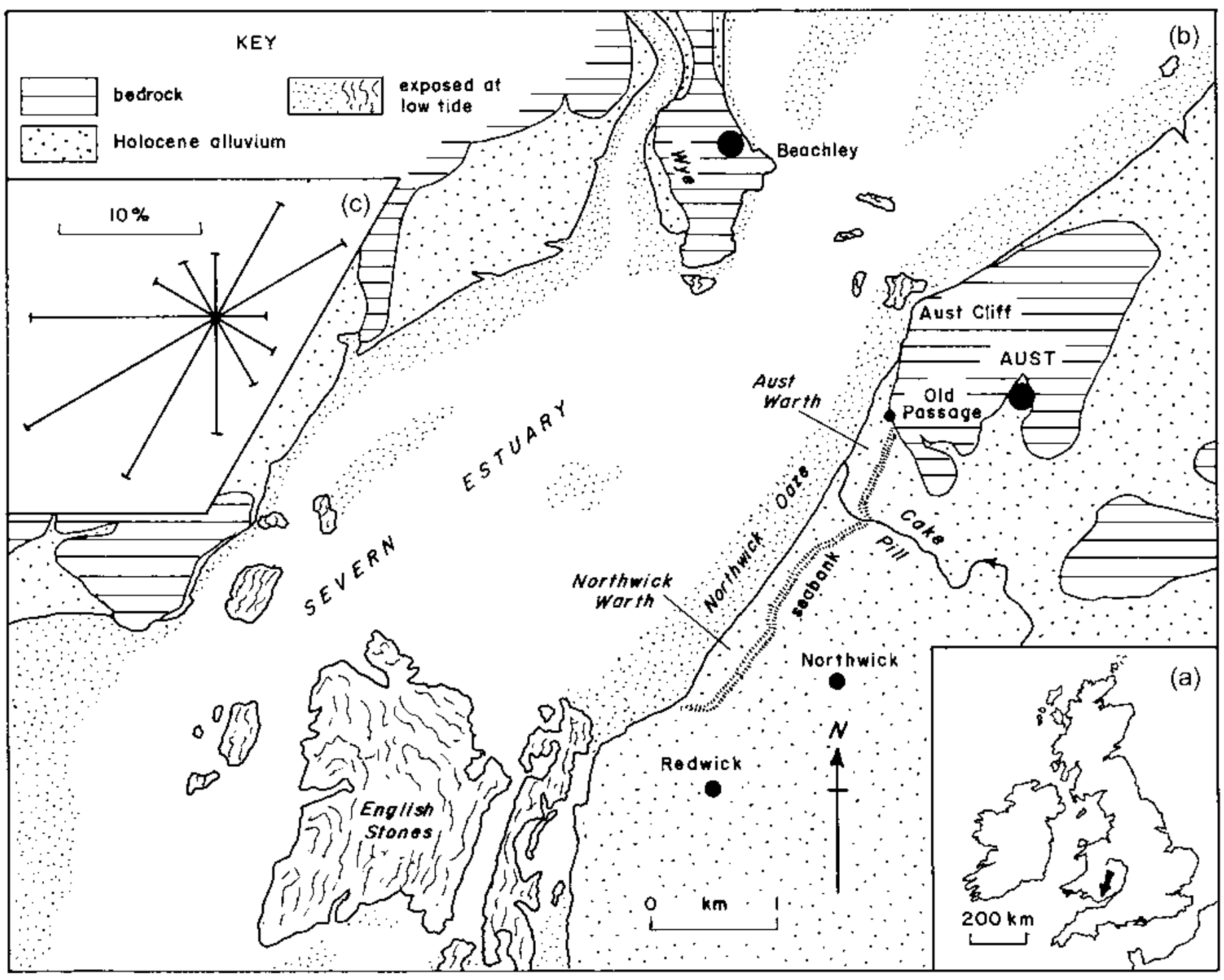

Figure 1. Northwick and Aust warths on the shore of the Severn Estuary. (a) The Severn Estuary in southwestern Britain; (b) the local setting of Northwick and Aust warths at the confluence of the Severn and Wye; (c) wind rose showing the directional frequency of mean daily winds measured at Avonmouth over the period 1970 to 1988.

Duffy (1998a, fig. 4) for the middle decades of the period of study in this paper, the area experiences frequent, strong winds from the west and southwest and, less often, gentler flows from the northeast (Fig. 1c). Swell waves do not reach the outer Severn Estuary. As the marshes and mudflat face toward the northwest, and are anchored between combinations of promontories and substantial intertidal ledges, they are affected at most states of the tide only by the local waves generated by modal winds. A consideration of shoreline alignment and shape and combined data on wind strength and direction over the medium term indicates that the wave power-supply to the coast is least toward the northeastern and southwestern anchor-points of the shoreline and greatest over the central portion. The piers for a former ferry across the Severn and for the power cable strung across the estuary are small, open structures and have no significant influence on marsh behaviour. Similarly, although larger, the piers for the two road bridges in the area have not made any noticeable effect on sedimentation.

\section{SOURCES OF EVIDENCE}

The main evidence for salt-marsh evolution at Northwick and Aust warths is a series of 12 historical maps and aerial surveys. Five high-quality topographic maps cover the period from 1822 to 1919 , the last three in the sequence 
being editions of the Ordnance Survey six-inch to the mile sheets. The earliest remote survey dates from March 1945 and is followed by others in late 1946, 1953 (incomplete), 1969, 1989, 1997 and 2007. A full ground survey was undertaken in 2007 using a Leica TC400 Total Station and staff with reference to local benchmarks surveyed to Ordnance Datum (Newlyn) (Haslett 2006); earlier ones are either at a reconnaissance level (1993) or cover only the northeastern half of the area $(1997,1998,2000,2002)$. The air photography available from 1959, 1960 and 1966 covers only limited parts of the marshes. By the end of the series of the 12 historical maps and aerial surveys, a descending sequence of three marsh-terraces had developed in the area (see Allen and Rae 1987, plate 2.2). The historical maps typically depict the generalized boundaries between the terraces and reveal only the largest gullies eroded into retreating scarps, particularly where artificial drains reached across the marsh. In the field, the clifflets between marsh-terraces commonly show a small-scale embayed topography. The aerial and satellite images were obtained at different times of year and are of variable technical quality. Some were secured under conditions that made it impossible to define the seaward extent of a marsh other than in the cartographer's terms of the generalized outer limit of marsh vegetation. For these reasons, in replotting these sources to a common scale, we have chosen to depict the extent of all the marshes using this generalized boundary, illustrating details with surface and aerial photographs. The youngest marshterrace is of most interest, and for it we give profiles of grain size and heavy metals.

\section{High marsh (Rumney Formation)}

The oldest, or high, marsh, traceable for almost 4 $\mathrm{km}$ along Northwick and Aust warths, is underlain by a sequence of pale-brown, texturally banded and laminated estuarine silts of unknown total thickness that grade up into about $20 \mathrm{~cm}$ of grey silts. These beds are assigned to the late Holocene Rumney Formation (Allen and Rae 1987), after a type-site near Cardiff (Allen 1987). The initial development of the formation here can be dated on ceramic grounds to not earlier than the late seventeenth century (Allen 1996). Evidence has since emerged, however, that at several places in the Severn Estuary two phases of the Rumney Formation are preserved, the earlier of late medieval origin (thirteenth or fourteenth century at earliest). The evidence is stratigraphical (including pottery) at Arlingham (Allen 2001) in the inner estuary, and morphostratigraphical in the middle estuary at Littleton (NGR ST 582907) and Woolaston (NGR ST 591981); at Littleton and Woolaston, a faint feature a few centimetres high and a subtle vegetation change separate two high marsh-terraces, each of which overlies pale brown silts below thin grey silts. There is no direct evidence yet for the date of inception of the beds at Northwick and Aust warths, but only the late phase may be present.

The high marsh was first mapped in 1822 (Fig. 2a). By 1835 a horizontal retreat of about $25 \mathrm{~m}$ had occurred along the southwestern part of Northwick Warth, declining to about $10 \mathrm{~m}$ toward Cake Pill and a just perceptible amount along Aust Warth (Fig. 2b). The slight embayments mapped at the outer ends of the drains that cross the marsh also generally indicate an erosional state. No marsh was present upstream of Old Passage. The seaward edge of the high marsh had become fixed by 1880 , for by then a new marsh had begun to form below the scarp along Aust Warth, much of Northwick Warth, and at Chestle Pill (Fig. 2c). Only over the southwestern portion of Northwick Warth was the scarp at the edge of the high marsh unencumbered and presumably still eroding. Between 1835 and 1880, the high marsh retreated by about $30 \mathrm{~m}$ in the southwest, declining to about $20 \mathrm{~m}$ toward Cake Pill and about $10 \mathrm{~m}$ along Aust Warth. These data imply an average annual retreat rate of not less than about $0.55 \mathrm{~m}$ overall.

\section{Intermediate marsh (Awre Formation)}

Like the high marsh, the intermediate marsh can be traced over the full length of Northwick and Aust warths. It overlies a thick sequence of texturally banded and laminated grey silts contaminated by heavy metals, attributed to the Awre Formation (Allen and Rae 1987). Between it and the high marsh is a well-defined clifflet of variable height, but in places reaching $0.4-0.5 \mathrm{~m}$. A variety of evidence from around the estuary places the inception of the Awre Formation some time in the second half of the nineteenth century (Allen and Rae 1987; Allen et al. 1990).

By 1880 the intermediate marsh was forming along large tracts of Northwick Warth and Aust Warth (Fig. 2c). The map of 1900 (Fig. 2d) shows new marsh rapidly infilling the wide, shallow embayment toward Chestle Pill, implying outward spreading at a rate of not less than about $10 \mathrm{~m}$ annually. Elsewhere at this general time the marsh-edge appears to have experienced only slight erosion, here and there with a little accretion (Figs. 2d, 2e). Significant erosion, however, was taking place by 1919 in the southwestern embayment (Fig. 2e), where a retreat of up to $30 \mathrm{~m}$ had occurred since 1900 over a wide front (Fig. 2 d).

There is a 26-year gap in the evidence between the 1919 map and the first aerial photographs of 1945 (Figs. 2e, f). During this interval erosion continued at a low rate at bold scarps in the embayment near Chestle Pill (Fig. 3a) and along the central sector of Northwick Warth. A more rapid retreat of up to about $20 \mathrm{~m}$ had occurred at Aust Warth, forcing the scarp so far inland as to locally intersect the outer edge of the high marsh (Fig. 3b). The initiation of another new marsh in two main zones sometime prior to 1945 had 


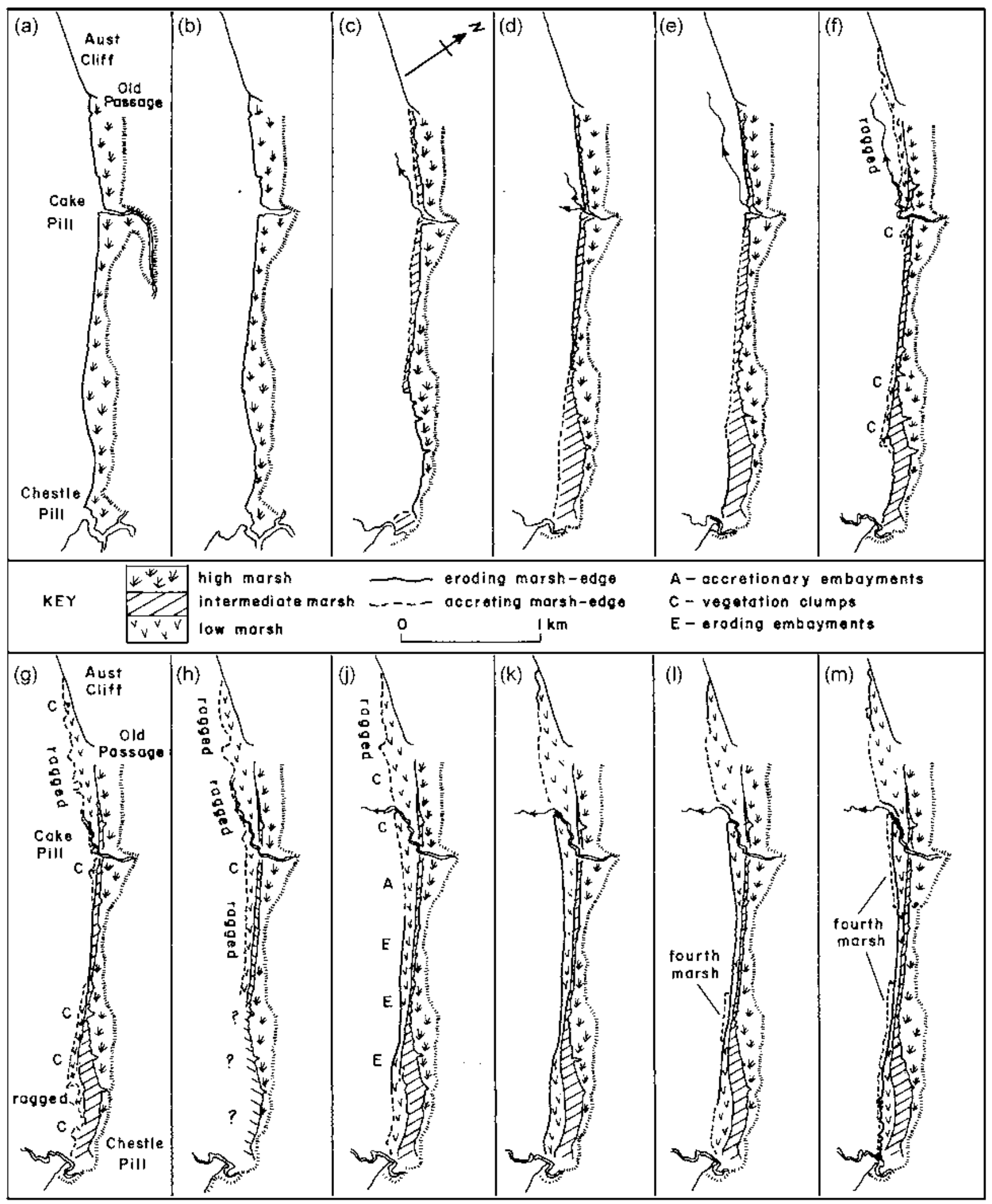

Figure 2. The development of Aust and Northwick warths from 1822 to 2007. (a) 1822 (Inclosure Awards); (b) 1835 (Commissioners of Sewers); (c) 1880 (Ordnance Survey); (d) 1903 (Ordnance Survey); (e) 1924 (Ordnance Survey); (f) March 1945 (Air photography); (g) November-December 1946 (Air photography); (h) June 1953 (Air photography); (j) April/June/July 1969 (Air photography); (k) June 1989 (Air photography); (l) May 1997 (Bath Spa University College; Strawbridge et al. 2000); (m) 2007 (Google Earth). 
stabilized the outer limit of the intermediate marsh over about half the extent of the warths (Fig. 2f).

\section{Low marsh (Northwick Formation)}

The low marsh is the youngest in the sequence of relatively mature marshes along Northwick and Aust warths. It is underlain by the Northwick Formation (Allen and Rae 1987), a sequence of grey, texturally banded and laminated estuarine silts strongly contaminated throughout by heavy metals. The beds exceed more than $2 \mathrm{~m}$ thickness in many places and, as can be seen on the bold, embayed cliff at the marsh-edge, rest sharply on a mainly wave-cut ravinement surface underlain by pale brown, banded silts of the Rumney Formation. The heavy-metal $(\mathrm{Zn}, \mathrm{Cu}, \mathrm{Pb})$ and rubidium $(\mathrm{Rb})$ contents were measured in 1984 in a long gully (NGR ST 533874) where the Northwick Formation was about 1.5 $\mathrm{m}$ thick and overlies the Rumney Formation (Allen and Rae 1987). Rubidium is a grain-size proxy inversely related to sand-silt content, increasing/decreasing within finer/ coarser sediments respectively. A weak upward-fining trend is evident in the Northwick Formation (Fig. 4), which is a little coarser than the underlying Rumney Formation. The heavy-metal values for the two formations are expressed in terms of Allen and Rae's (1987) grain-size corrected indices $\mathrm{I}_{\mathrm{Zn}}, \mathrm{I}_{\mathrm{Cu}}$ and $\mathrm{I}_{\mathrm{Pb}}$, the largest absolute amounts of $\mathrm{Zn}, \mathrm{Cu}$ and $\mathrm{Pb}$ measuring $312 \mathrm{ppm}, 51 \mathrm{ppm}$ and $100 \mathrm{ppm}$ respectively. Two heavy-metal peaks are evident, at depths of about 0.33 $\mathrm{m}$ and about $0.73 \mathrm{~m}$. According to French (1996), the lower dates to CE $1936 \pm 7$ years and the higher to $1958 \pm 4$ years.

The development of the low marsh can be followed much more closely and reliably than the older marshes. By March 1945 (Fig. 2f) it was present on the mudflat from a little downstream from Cake Pill to upstream of Old Passage and upstream of the embayment at Chestle Pill. The vegetated area rapidly spread laterally. By the end of 1946 (Fig. 2g), it had entered the embayment (Fig. 3a), partly as isolated clumps of pioneer plants, and far to the northeast had spread outward to the channel of Cake Pill on the mudflat. As in similar situations in San Francisco Bay (Watson 2008), the advancing edge at Cake Pill and Old Passage was very ragged, as the pioneer vegetation was restricted to the barely perceptible levees of the many small gullies that drained across the mudflat (Fig. 3b). The low marsh was best developed immediately to the northeast of the embayment, where many clumps of pioneer vegetation appeared along its outer margin. At this stage, a bold scarp, denoted in the photographs by a deep shadow, existed everywhere along the edge of the intermediate marsh. Only in a central zone, several hundred metres southwest of Cake Pill, was the scarp unencumbered by vegetation at its foot (Fig. 3c). By 1953 , however, although the coverage is incomplete, a marsh about $100 \mathrm{~m}$ wide with a ragged margin had appeared here, and further advances had occurred around Cake Pill and
Old Passage (Fig. 2h). New marsh now lined both banks of the long, northeasterly course of Cake Pill, but this channel had not yet been abandoned.

The edge of the gradually maturing low marsh began to retreat sometime late in the interval between 1953 and 1969. The ragged, accretionary margin, widely evident in 1953 and in the incomplete coverages of 1959 and 1960, had been locally replaced by 1969 (Fig. 2j) by an irregular, coarsely saw-toothed edge formed of bold spurs and furrows separated by low, shadow-casting scarps (Fig. 3d). This distinctive topography, Allen's (1993) cliffed and embayed type of margin, resembles the "cleft and neck" structure described by Schwimmer (2001) from eroding Delaware salt marshes. The erosional zone at Northwick Warth extended for a distance between about $0.5 \mathrm{~km}$ and 1.85 $\mathrm{km}$ northeastward from Chestle Pill. Elsewhere the marsh continued to advance and build up. In the embayment at Chestle Pill the ragged features at the marsh-edge had been consolidated into several broad bays and headlands focused on gullies (Fig. 3e). A similar but much less marked change occurred around Old Passage and Cake Pill, where another series of bays had developed at the marsh-edge. The low marsh as a whole was built up and matured by 1969 to such an extent as to reduce to a slight feature the bold scarp that at first defined the outer limit of the intermediate terrace. Figure $2 \mathrm{k}$ shows the situation in 1989, after a 20 -year gap. The low marsh was in retreat over almost the whole frontage, at an average annual rate of up to about a metre, with the exception of a still-accreting portion in the embayment at Chestle Pill and another between Cake Pill and Old Passage. By now Cake Pill had clearly adopted a new northerly course, the earlier northeasterly one just being evident in the well-established marsh. The bays and headlands in the northeastern part of the embayment at Chestle Pill showed signs of erosion, and for several hundred metres southwest of Cake Pill a cleft-and-neck topography appeared. In the long intervening stretch, the retreating marsh-edge took the form of a bold, wide ramp of exposed marsh silts with clefts and necks at the level of the marsh-platform (Fig. 3f). As the air photography reveals, numerous blocks of silt that had toppled (Allen 1989) from this periodically undercut scarp lay scattered over the mudflat below.

A reconnaissance-level ground survey of the marshedge yielding vertically-accurate profiles was made in 1993 (Fig. 5a). A smooth transition from mudflat to marsh over an inflected, convex-up profile was observed between Cake Pill and Old Passage (Figs. 5a.1, 5a.2) and close to Chestle Pill (Fig. 5a.12). Elsewhere a locally complex scarp or ramp exposing silts divided the two environments. This feature, no more than a few to several decimeters high near the smoothly transitional areas (Figs. 5a.3, 5a.4, 5a.10, 5a.11), grew in height to over $3 \mathrm{~m}$ in the central sector (Figs. 5a.59), locally adding an upper ledge of bare sediment to the eroded margin. 

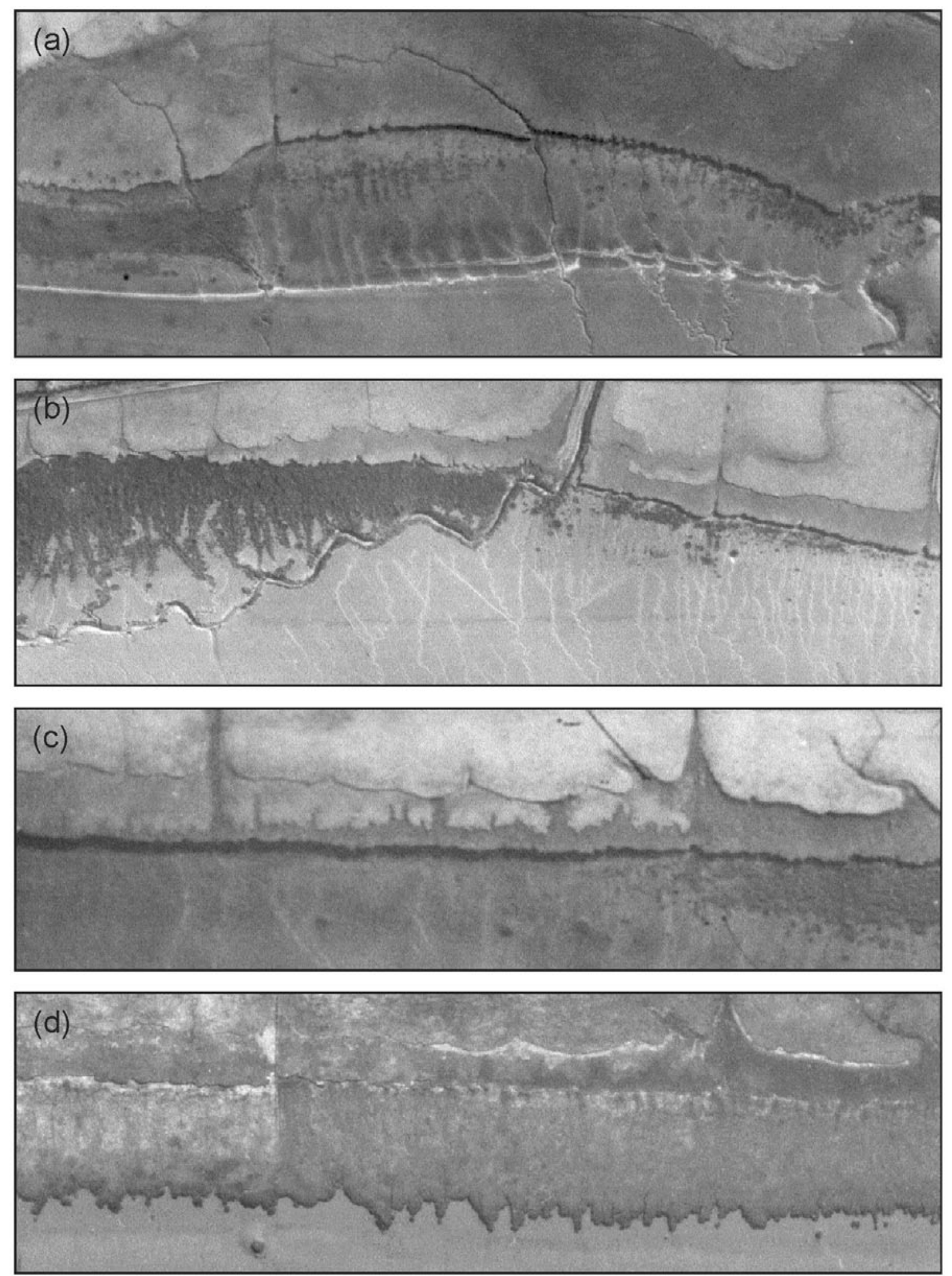

Figure 3. Aerial photographs of Northwick and Aust warths. (a) bay-like feature with bold cliff at Chestle Pill (1100 $\mathrm{m}$ long, 18 December 1946, 4017A UK 1903); (b) intersection of intermediate marsh cliff with high marsh cliff at Cake Pill (950 m long, 4 December 1946, 3201 UK 1871); (c) bold scarp in central zone (450 m long, 18 December 1946, 4017B UK 1903); (d) central zone ridge and furrow topography (900 m long, 18 April 1969, 69 118A); 

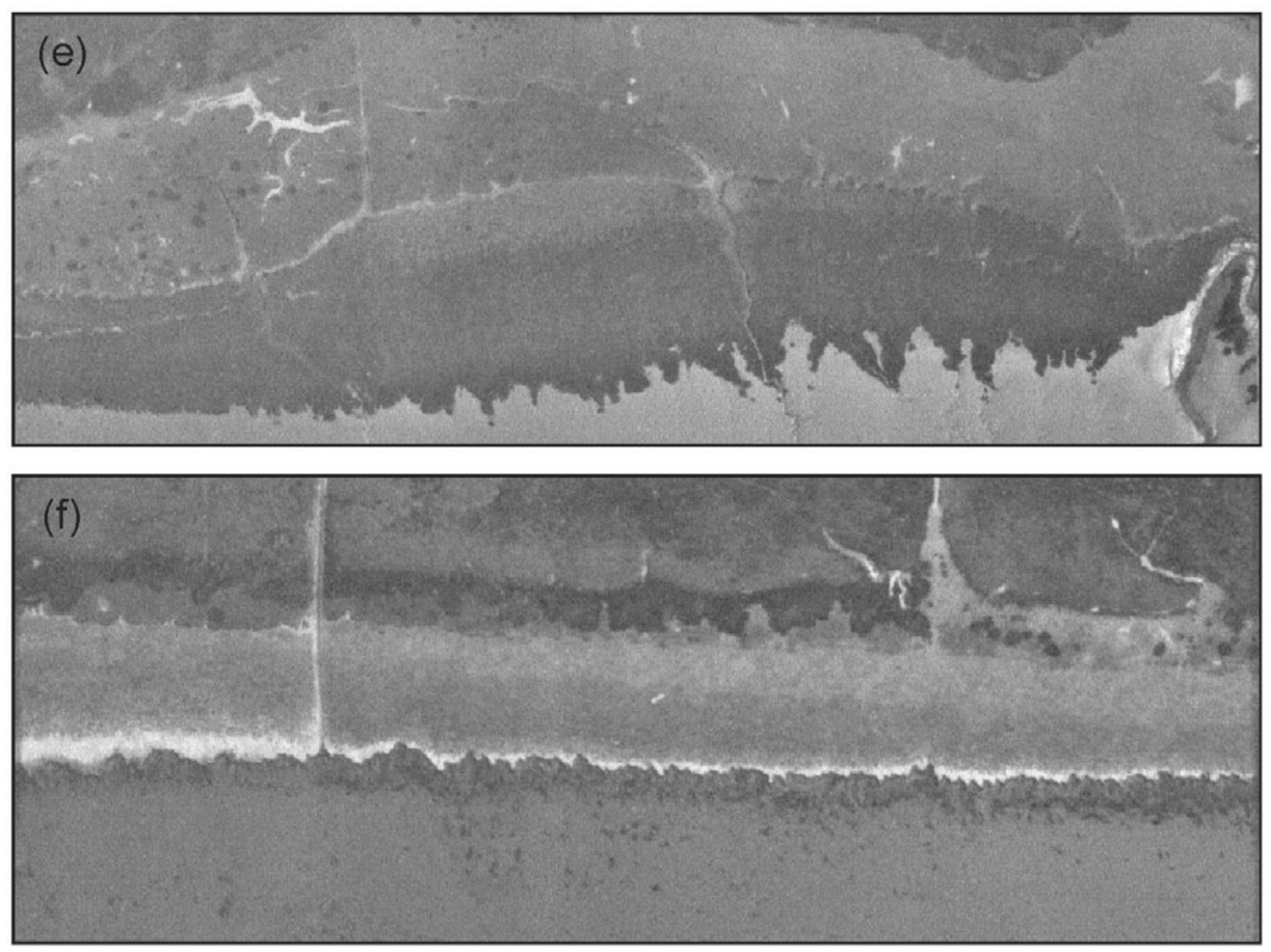

Figure 3 continued. (e) headlands, gullies and Chestle Pill embayment (800 m long, 30 June 1969, 69 311); and (f) ramp, clefts and necks in the central zone (750 m long, 18 June 1989, 89 301A).

\section{A fourth marsh}

The aerial imagery of 1997 used by Strawbridge et al. (2000) brings the first hint of significant change (Fig. 2l). In the interval since 1989 there had been a slight lateral extension of the eroded edge of the low marsh, but more noticeably the appearance at the foot of the scarp, about one kilometre northeast of Chestle Pill, of a narrow belt some $10-15 \mathrm{~m}$ wide and $350 \mathrm{~m}$ long of pioneer vegetation. This strip of halophytes represents the birth of a fourth marsh at Northwick Warth. As observed by van de Koppel et al. (2005) and van der Wal et al. (2008) from the relatively sheltered marshes they studied, and by Pedersen and Bartholdy (2007) from an exposed context, a narrow zone of unvegetated mud separated the new marsh from the bold scarp at the edge of the low marsh. In the case of the marshes of the Danish Wadden Sea, this zone, taking the form of a channel (landpriel), persists over the entire build-up of the new marsh (Jakobsen 1954; Pedersen and Bartholdy 2007). Such a feature is not seen along the inner margins of the substantially matured intermediate and low marshes at Northwick and Aust warths. We must conclude therefore that, in the muddy Severn Estuary, the feature equivalent to a landpriel gradually disappear as marshes mature.

Subsequently the fourth marsh rapidly spread laterally. In 2007 (Fig. 2m) it was present in discontinuous patches in the embayment at Chestle Pill, as continuous belts for some $650 \mathrm{~m}$ northeast of the embayment and southwest of Cake Pill, and in small developments northeast of Old Passage. Only in a short, central zone about $550 \mathrm{~m}$ long was the marsh not detectable at this date. It had gained little elevation, however, and the unprotected edge of the low marsh continued almost everywhere to erode.

The mainly erosional status of the edge of the low marsh was confirmed in 2008 by an instrument survey of ten transects (Fig. 5) across the marshes as a whole, with an eleventh dating from 2004 (Fig. 5b.2), and a photographic walk-over in 2007 (Fig. 6). A markedly convex-up, gradational profile with a slight inflection in two of the three transects typifies the still-accreting portion of the low marsh between Cake Pill and Old Passage (Figs. 5b.1-3, 7a). Convex-up profiles persist for several hundred metres southwestward from Cake Pill, but are truncated at the foot by increasingly tall scarps (Figs. 5b.4, 5b.5). Abutted 


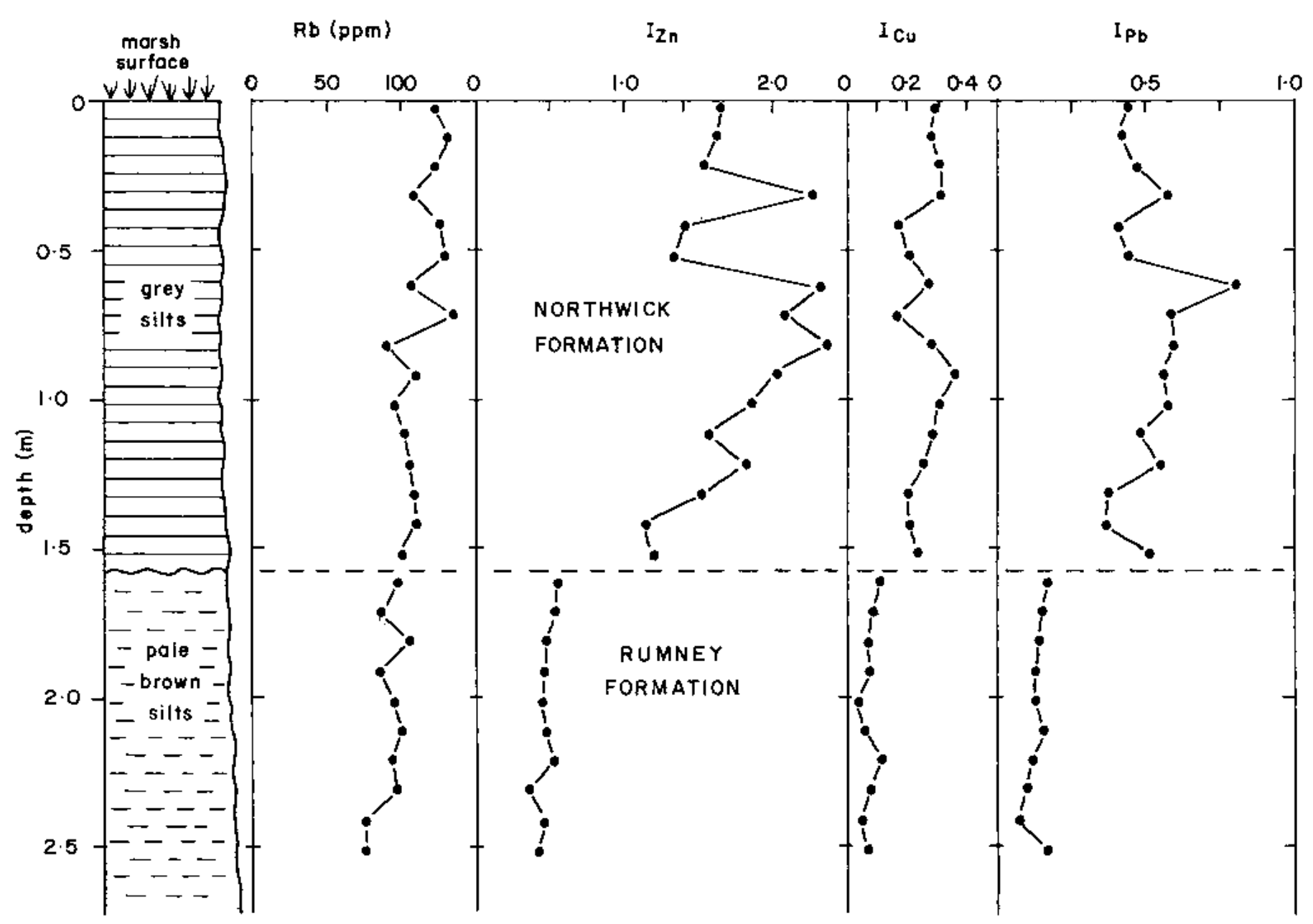

Figure 4. Geochemical profile (collected 1986) of the Rumney and Northwick Formations on Northwick Warth. See Fig. 5 a for sample location.

by a substantial development of the fourth marsh (Fig. 6b), these scarps have a ragged appearance and seem to be only gradually eroding. In the central sector of the marshes, a bold, actively retreating ramp and scarp occur at the edge of the low marsh (Figs. 5b.6, 5b.7). A cleft-and-neck topography is evident at platform level and by 2008 the fourth marsh had faded to scattered clumps of low-lying vegetation sited off the scarp on a slope of largely bare silt (Fig. 6c). The toppling of blocks of silt has allowed several of the necks in this sector to evolve into Schwimmer's (2001) pinched form and cut-off stacks. The fourth marsh gradually reappears in a substantial development further still to the southwest (Figs. 6d, 6e), with evidence of a feature corresponding to a landpriel. The measured transect here reveals a scarp about $2 \mathrm{~m}$ high against which the fourth marsh is banked (Fig. 5b.8). The scarp weakens locally to nothing as the low marsh is traced toward and into the embayment at Chestle Pill (Figs. 5b.9, 5b.10), where the fourth marsh in places is hard to distinguish from its predecessor. Shallow pits and furrows in which silt is exposed cover the outer part of the marsh-platform here (Figs. 6f, 6g). The fourth marsh is variably developed, in places weak with a potential landpriel (Fig. 6f) and in others banked high against the edge of the low marsh (Fig. 6g). A convex-up profile is seen again in the southwestern part of the embayment (Fig. 5b.11), where the fourth marsh has grown up to fill to the rim a number of small bays at the edge of the low marsh, and so extend the slope of the latter (Fig. 6h).

\section{DISCUSSION}

Using chiefly historical evidence we have outlined how the salt marsh at Aust and Northwick warths in the Severn Estuary evolved during recent centuries over a frontage of about $4 \mathrm{~km}$ in a stepwise manner on a decadal-centennial 


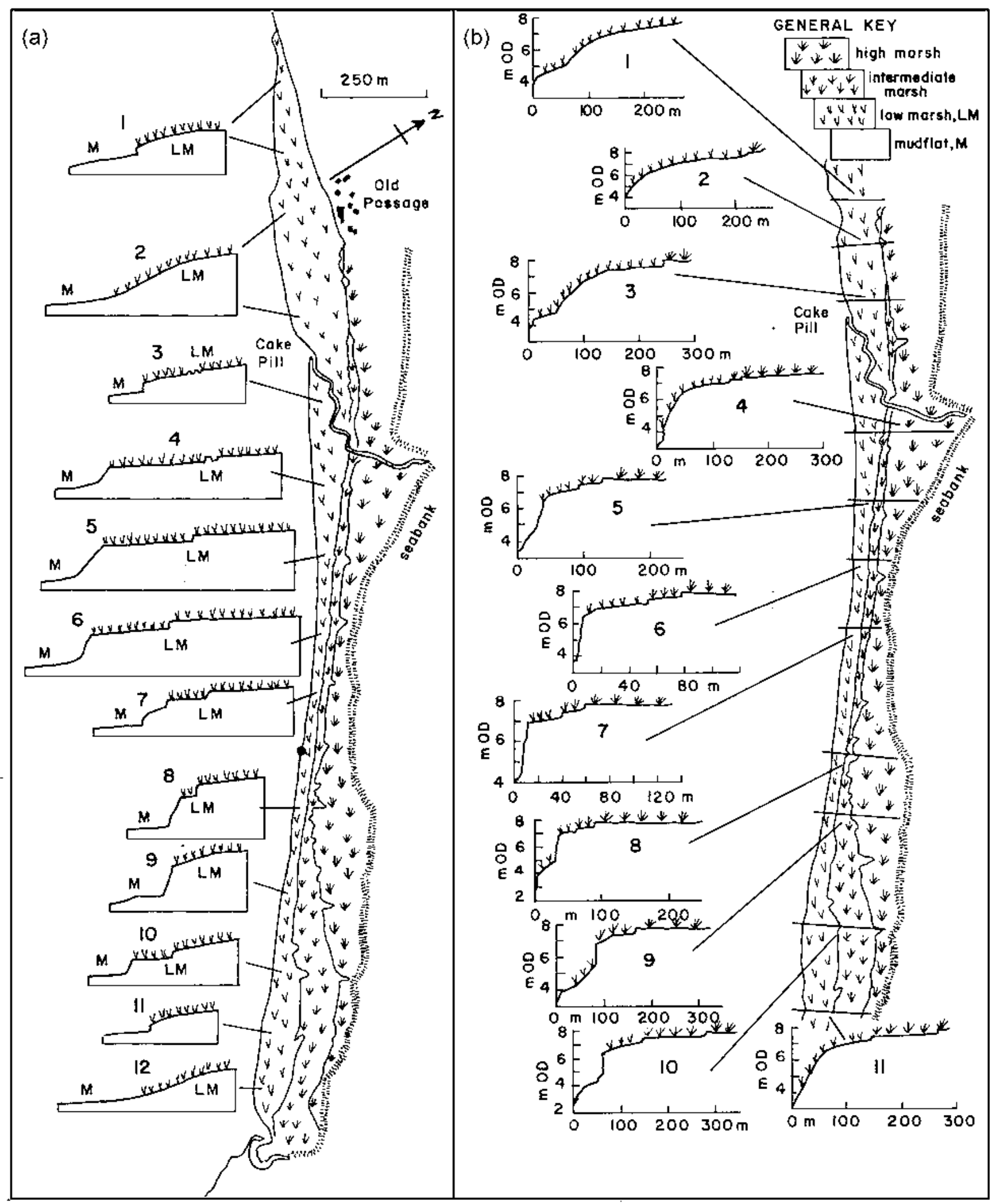

Figure 5. Transects across Aust and Northwick warths. (a) freehand sketched profiles (1993), not to scale, across the outer edge of the low marsh (these profiles reveal more detail than can be shown in the measured profiles of $b$ ); (b) measured profiles across marshes (2007, except for 2 dating from 2004), from the mudflat to the road (Aust Warth) or foot of the seabank (Northwick Warth). The location of the geochemical profile (Fig. 4) is shown in (a) as a filled circle. Abbreviations: $M=$ mudflat; $L M=$ low marsh. 

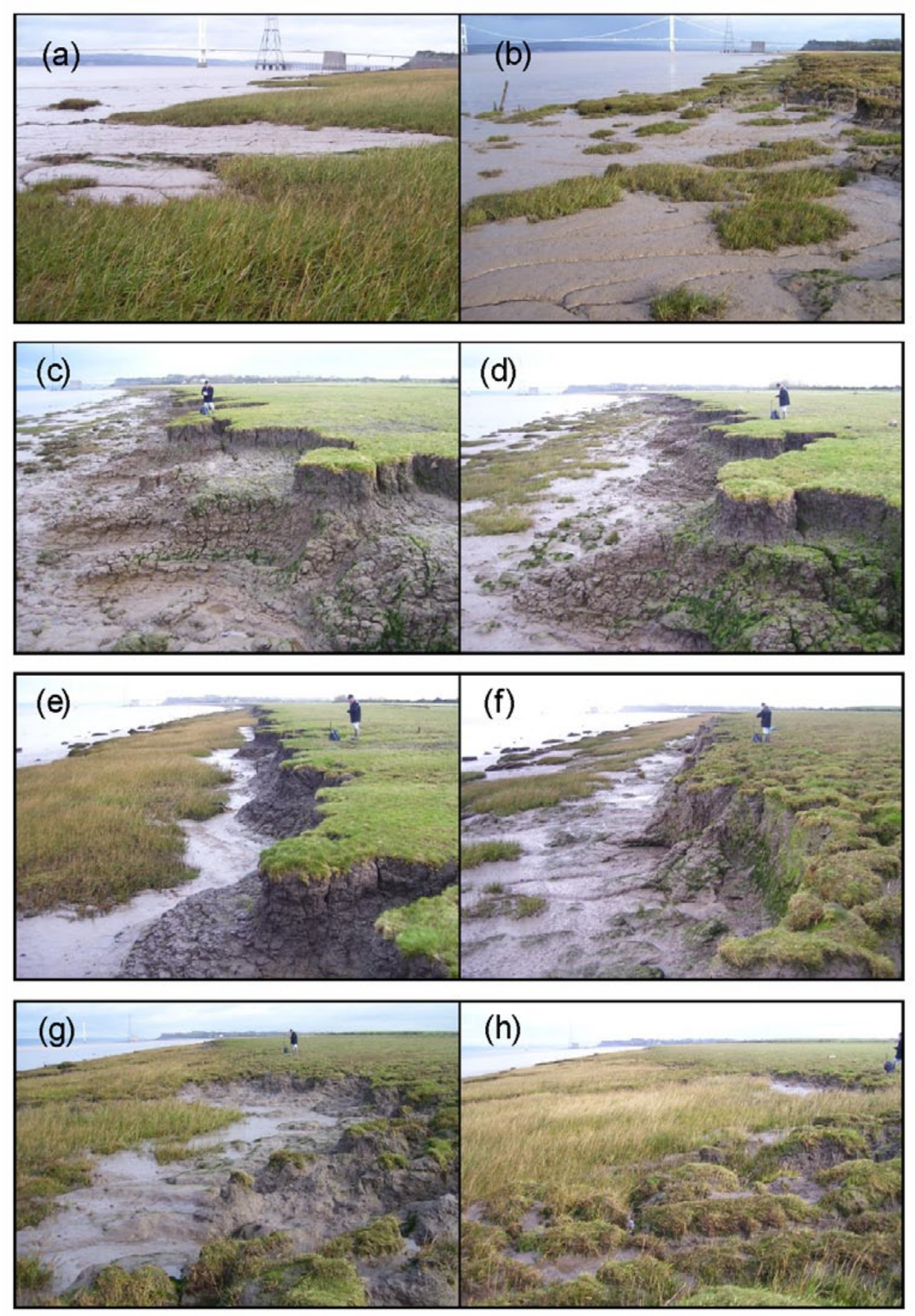

Figure 6. Photographic walk-over of Northwick and Aust warths (taken 8 November 2007). (a) accreting marsh, Aust Warth (view to north from NGR ST 5611 8812); (b) uneven development of fourth marsh and low, ragged margin to predecessor (view to north from NGR ST 5583 8817); (c) cleft-and-neck eroding margin to third marsh with scattered traces of fourth marsh (view to north from NGR ST 5558 8776); (d) reappearance of fourth marsh below bold cleft-and-neck margin of predecessor (view to north from NGR ST 5533 8745); (e) strong development of fourth marsh (view to north from NGR ST 5518 8728); (f) pitted and eroded outer part of third marsh platform (view to north from NGR ST 5495 8703); (g) confused, partly eroded topography at marsh edge, near Chestle Pill (view to north from NGR ST 5483 8686); (h) fourth marsh infilling ragged embayments, near Chestle Pill (view to north from NGR ST 5476 8677). 
time scale. We have recognized at least four phases of upward and outward marsh growth, each separated by a phase of marsh-edge retreat at a bold, eroding cliff associated with a shore platform that, in the case of the older marshes, became largely concealed behind and below new marsh silts. The oldest marsh (high marsh, Rumney Formation) dates from not earlier than the late-seventeenth century; next, an intermediate marsh (Awre Formation) was initiated prior to 1880; and more recently, a low marsh (Northwick Formation) began to form some time before 1945 (Allen and Rae 1987). Erosional retreat of this marsh began in the 1960s and is now active along most of the frontage. In one sheltered locality, however, upward and outward growth is continuing. Some time in the 1990s, simultaneously with this local advance, a fourth marsh appeared in front of the low marsh cliff and is now spreading and building along the frontage.

Common to the silts of all these phases of marsh is the presence ofcentimetre-scale texturalbanding and millimetresubmillimetre scale lamination. These important structures point to rapid upward marsh growth, especially during the earlier developmental stages, at rates greatly in excess of local water-level rise (e.g., Pethick 1981; Allen 1990a). The banding compares closely with the annual banding described from a number of mid-Holocene and modern salt-marsh silt deposits in the Severn Estuary (Allen 1990a, 2004; Dark and Allen 2005b; Allen and Haslett 2006), where accretion rates on mudflats and low marshes can be high (Allen and Duffy 1998b; Allen and Dark 2008). Sediment supply and siltation rates in the turbid Severn Estuary are amply sufficient to maintain salt-marsh platforms high in the tidal frame (Allen 1990b; Haslett 2011).

The salt marshes overlying these silts at Aust and Northwick warths are clearly cyclical, but are they autocyclic? What factors other than autocyclicity could explain the sequential episodes of tidal salt-marsh destruction and reformation we have recorded? Chapman (1960) explained such terraced salt marshes by invoking sea-level change, a non-local allocyclic factor. Gao and Collins (1997) considered that salt marshes could become cliffed during sea-level rise. A rising relative sea-level apparently favours coastal erosion, but terraced marshes also occur where levels are falling (see Allen 2000). Numerical modelling suggests that higher rates of sea-level rise are more likely to lead to marsh-edge erosion and, indeed, marsh submergence under very high rates of rise (Mariotti and Fagherazzi 2010). So far as the present marshes are concerned, relative sea-level, as recorded at Avonmouth (Woodworth 1990; Woodworth et al. 1999), is rising smoothly and without the abrupt movements that could trigger coastal change. Theoretically, salt-marshes respond with a lag to water-level change (Allen 1995; Kirwan and Murray 2005, 2007), but only abrupt changes seemingly evoke abrupt responses. Ordinary sea-level change therefore, seems an unlikely forcing factor. Sediment supply, undoubtedly limiting saltmarsh occurrence (French 2006), may also be discounted, for in the area we describe a fourth marsh paradoxically is forming in front of the low marsh, in retreat over most of the frontage but still advancing in a sheltered part. Some investigators favour medium-term changes in wind direction and consequent wave-activity as the cause of terraced salt marshes (see Allen 2000). The only time-series of suitable length and quality appropriate to the Severn Estuary are Lamb's sequence (1861-1994) of "subjective" national weather types (Lamb 1972; Kelly et al. 1997) and the corresponding (1880-2009) "objective" version (Jenkinson and Collison 1977; Jones et al. 1993). Essentially, these schemes classify the daily weather as of northerly, northwesterly, westerly, southerly or easterly type, the first three being relevant here (Fig. 7). Marsh erosion could be promoted by a relatively high annual incidence, regardless of trend, of these types associated with strong winds (Fig. $1 c)$, whereas a low incidence could favour accretion; trend is considered less significant than incidence relative to the long-term average. With disagreement in only three out of 24 cases, and one undecided (Table 1), the sedimentary activity evidenced at Aust and Northwick warths appears to fit these weather patterns well, especially in the case of the westerly type, which includes the prevailing winds. Once initiated, cliffs in salt-marsh and similar weak deposits may be expected to retreat at rates increasing non-linearly with wave-power (Kamphuis 1987; Schwimmer 2001).

Salt marshes abound in the Greater Thames area on the east coast of Britain. There is some local salt-marsh cyclicity (Greensmith and Tucker 1965; Harmsworth and Long 1986), but the general trend since Roman times has been unsteady marsh-edge retreat and/or creek-widening. Van der Wal and Pye (2004) analysed eleven natural or human factors that could have promoted such unsteady development. While recognizing that more than one forcing factor was at work, depending on locality, van der Wal and Pye (2004) concluded that changes in storminess and windwave climate were most influential, the marshes retreating more rapidly when these extrinsic factors were augmented. Augmentation is evident from local measurements and, less clearly over the longer term, from the changing incidence of easterly and southerly weather types (Lamb 1972; Jones et al. 1993; Kelly et al. 1997). The only intrinsic factor vegetation die-back - was discounted, offering van der Wal and Pye (2004) no evidence for marsh autocyclicity in the Greater Thames.

Salt marshes that appear to be cyclic occur along the broadly east-west trending Westerschelde in The Netherlands. Eight mature marshes (five on the southern shore) were analysed by van der Wal et al. (2008) using a 30 -year run of aerial photographs (1975-2004). The lack of spatial synchrony in their response is not surprising, as the marshes differ significantly in context. At south-facing 


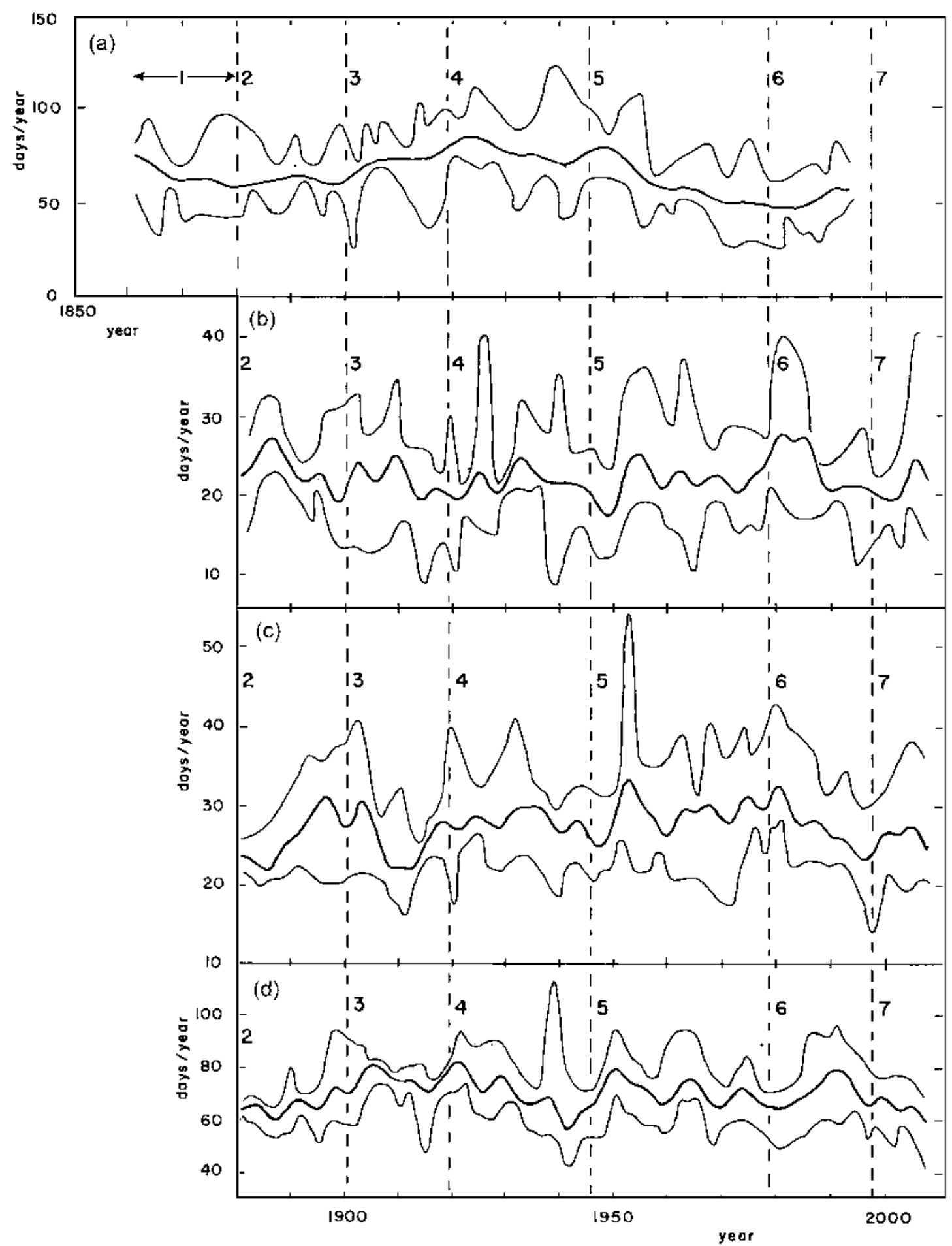

Figure 7. National trends in weather type and windiness (days/year) over approximately the last 150 years. (a) westerlytype days according to Lamb's (1972) "subjective" method; (b) Northerly-type days according to the objective methods of Jenkinson and Collison (1977) and Jones et al. (1993); (c) northwesterly-type days according to objective methods; (d) westerly-type days according to objective methods. Each trend is depicted in terms of a moving average (heavy line) and envelope lines giving an impression of inter-annual variation. The dashed vertical lines refer to the selected activities listed in Table 1. 
Table 1. Relationship of sedimentary activity at Northwick and Aust warths to the incidence (highs, lows) of subjective (Lamb 1972; Kelly et al. 1997) and objective (Jenkinson and Collison 1977; Jones et al. 1993) British weather types (see also Fig. 7).

\begin{tabular}{|c|c|c|c|c|}
\hline \multirow[b]{3}{*}{ Activity } & \multicolumn{4}{|c|}{ Types } \\
\hline & Subjective & & Objective & \\
\hline & westerly & northerly & northwesterly & westerly \\
\hline 1. $1860-80$, high marsh eroding & A & ? & $?$ & $?$ \\
\hline 2. 1880 , intermediate marsh accreting & A & NA & A & A \\
\hline 3. 1900 , intermediate marsh accreting/stable & A & A & NA & A \\
\hline 4. 1919 , intermediate marsh eroding & A & NA & A & A \\
\hline 5. 1945 low marsh accreting & A & A & A & A \\
\hline 6. Late 1960 s, low marsh accreting but locally eroding & A & A & A & A \\
\hline 7. 1997 , low marsh widely eroding but some local accretion; fourth marsh appears & $?$ & A & A & A \\
\hline
\end{tabular}

Abbreviations: $\mathrm{A}=$ agreement; $\mathrm{NA}=$ no agreement

Zuidgors there was continuous and at first rapid retreat of the marsh-edge cliff, although by the later years a few small clumps of pioneer vegetation had appeared far out on the mudflat. This can be compared to the retreat of the high marsh at Aust and Northwick warths and the inception of the fourth marsh (Figs. 2a, 2b, 2m). By contrast, at northfacing Hellgatpolder (see also van de Koppel et al. 2005), retreat was generally slower and, present at the start of the survey, a wide belt of large, progressively spreading and fusing clumps of pioneer marsh gradually built up off the marsh-cliff beyond a barren zone. A parallel may be drawn with the early growth of the intermediate and low marshes at Aust-Northwick (Figs. 2c, 2d, 2f-j). At sheltered Hoofdplaat and Thomaespolder, a pioneer marsh without a landpriel had grown in front of a stable cliff. Supporting the possibility of autocyclicity according to the van de Koppel et al. (2005) model, van der Wal et al. (2008) emphasized the role of intrinsic factors in determining the response of the Westerschelde marshes, especially the positive feedback between sedimentation and buffering tussocks of pioneer Spartina (see also Callaghan et al. 2010).

From a 42-year survey of the exposed sandy coast of the Danish Wadden Sea, Pedersen and Bartholdy (2007) described cyclic marshes that had evolved on a decadal timescale to seaward of coastal embankments. Each growing marsh consisted of a landward-sloping platform bounded to seaward by a low cliff, in front of which was a shallow, leveed, marsh-parallel channel or landpriel. Eventually, the sandflat on the seaward side of this creek built up sufficiently for pioneer plants to take hold, whereupon positive feedback between sedimentation and plant growth created a new marsh that in time partly obliterated the creek as a surface feature. The implication is that the Danish marshes are autocyclic, but Pedersen and Bartholdy (2007) did not examine the possible role of external forcing factors.

The Aust-Northwick marshes exhibit many features expected of autocyclic marshes (Gao and Collins 1997; van de Koppel et al. 2005) and observed from marshes claimed as autocyclic, but also give evidence for a degree of external control (Table 1). Could the Severn Estuary marshes be autocyclic but with the autocyclicity substantially locked into the pattern of extrinsic factors? The van de Koppel model predicts the gradual build-up during marsh growth of an increasingly steep $\left(\leq \mathrm{ca} .10^{\circ}\right)$ intermediate zone between the mudflat and the marsh-platform. Such an accretionary zone of this order of steepness is seen on the low marsh at sheltered Aust Warth (Figs. 5a.1, 5a.2) and was observed by van de Koppel et al. (2005) from a Friesian salt marsh (Schiermonnikoog) several decades old. The time-scale in the model for development to this near-critical state is about 150 years. Subsequently, in the model, a "disturbance" (e.g., a storm) leads to vegetation collapse and the initiation of a landward-retreating cliff; such developments are well known, and not just from the Severn Estuary. The model and the Dutch and Danish field evidence thus combine to assign a decadal-centennial time-scale to the path from marsh inception to cliffing. It seems significant that this is not only the time-scale for marsh development at Aust and Northwick warths but also that of the medium-term weather changes that affect the area (Fig. 7, Table 1).

There can be little doubt about the critical role of positive feedback between sedimentation and plant growth during the first stage of marsh creation, as Yapp et al. (1917) proposed. What are not yet understood in a purely autocyclic model are the circumstances in the second stage when, after cliff retreat, a new marsh arises. In the model of van de Koppel et al. (2005), a new marsh appears only through the incomplete erosion of the lowermost vegetation on the prior marsh, an effect not observed, at least in the Severn Estuary. Gao and Collins (1997) did not model this stage but suggested that cliff retreat could widen the tidal flat sufficiently that waves no longer broke in front of the marsh. It is also possible that a combination of cliff erosion and vertical marsh growth could shape a cliff so tall that 
accretion followed by plant colonization could begin at the foot, an effect that, at our Severn Estuary site, would be favoured by the reduced wave-activity associated with a lowered incidence of westerly days.

\section{ACKNOWLEDGEMENTS}

This paper is a contribution to UNESCO International Geoscience Programme (IGCP) Project 588 "Preparing for Coastal Change". The authors are grateful to Adam Rogers for assistance in the field, and to Jessica Williams for administrative assistance. The authors thank Chris Spencer and Danika van Proosdij for their helpful reviews of an earlier draft of this paper and journal editor Rob Fensome for the helpful comments and suggestions.

\section{REFERENCES}

Allen, J.R.L. 1987. Late Flandrian shoreline oscillations in the Severn Estuary: the Rumney Formation at its typesite (Cardiff area). Philosophical Transactions of the Royal Society, B315, pp. 157-184. http://dx.doi.org/10.1098/ rstb.1987.0006

Allen, J.R.L. 1989. Evolution of salt-marsh cliffs in muddy and sandy systems: a qualitative comparison of British west-coast estuaries. Earth Surface Processes and Landforms, 14, pp. 85-92. http://dx.doi.org/10.1002/ esp.3290140108

Allen, J.R.L. 1990a. Saltmarsh growth and stratification: a numerical model with special reference to the Severn Estuary, southwest Britain. Marine Geology, 95, pp. 7796. http://dx.doi.org/10.1016/0025-3227(90)90042-I

Allen, J.R.L. 1990b. The Severn Estuary in southwest Britain: its retreat under marine transgression, and fine-sediment regime. Sedimentary Geology, 66, pp. 13-28. http:// dx.doi.org/10.1016/0037-0738(90)90003-C

Allen, J.R.L. 1993. Muddy alluvial coasts of Britain: field criteria for shoreline position and movement. Proceedings of the Geologists' Association, 104, pp. 241-262.

Allen, J.R.L. 1995. Salt-marsh growth and fluctuating sealevel: implications of a simulation model for coastal stratigraphy and peat-based sea-level curves. Sedimentary Geology, 100, pp. 21-45. http://dx.doi.org/10.1016/00370738(95)00101-8

Allen, J.R.L. 1996. An early post-medieval timber setting and subrectangular diggings in late Flandrian estuarine sediments, Rumney Great Wharf, Gwent. Archaeologia Cambrensis, 145, pp. 152-168.

Allen, J.R.L. 2000. Morphodynamics of Holocene salt marshes: a review sketch from the Atlantic and southern North Sea coasts of Europe. Quaternary Science Reviews, 19, pp. 1155-1231, (Erratum) pp. 1839-1840.

Allen, J.R.L. 2001. A medieval waterside settlement overlooking Severn Estuary alluvium, Hock Cliff, Fretherne and Saul, Gloucestershire. Archaeology in the Severn Estuary, 12, pp. 79-98.

Allen, J.R.L. 2004. Annual textural banding in Holocene estuarine silts, Severn Estuary Levels (SW Britain): patterns, cause and implications. The Holocene, 14, pp. 536-552. http://dx.doi.org/10.1191/0959683604hl730rp

Allen, J.R.L. and Dark, P. 2008. Seasonality of modern pollen and sediment deposition in an estuarine context: the Severn Estuary Levels, southwest England. Journal of Quaternary Science, 23, pp. 213-228. http://dx.doi. org/10.1002/jqs.1138

Allen, J.R.L. and Duffy, M.J. 1998a. Temporal and spatial deposition patterns in the Severn Estuary, southwestern Britain: intertidal studies at spring-neap and seasonal scales. Marine Geology, 146, pp. 147-171. http://dx.doi. org/10.1016/S0025-3227(97)00124-2

Allen, J.R.L. and Duffy, M.J. 1998b. Medium-term sedimentation on high intertidal mudflats and salt marshes in the Severn Estuary, SW Britain: the role of wind and tide. Marine Geology, 150, pp. 1-27. http:// dx.doi.org/10.1016/S0025-3227(98)00051-6

Allen, J.R.L. and Haslett, S.K. 2006. Granulometric characterization and evaluation of annually banded midHolocene estuarine silts, Welsh Severn Estuary (UK): coastal change, sea level and climate. Quaternary Science Reviews, 25, pp. 1418-1446. http://dx.doi.org/10.1016/j. quascirev.2005.12.009

Allen, J. R. L. and Haslett, S. K. in press. Site formation processes in the Severn Estuary Levels. Archaeology in the Severn Estuary.

Allen, J.R.L. and Rae, J.E. 1987. Late Flandrian shoreline oscillations in the Severn Estuary: a geomorphological and stratigraphical reconnaissance. Philosophical Transactions of the Royal Society, B315, pp. 185-230. http://dx.doi.org/10.1098/rstb.1987.0007

Allen, J.R.L., Rae, J.E., and Zanin, P. 1990. Metal speciation $(\mathrm{Cu}, \mathrm{Zn}, \mathrm{Pb})$ and organic matter in an oxic salt marsh, Severn Estuary, Great Britain. Marine Pollution Bulletin, 21, pp. 574-580. http://dx.doi.org/10.1016/0025326X(90)90606-9

Callaghan, D.P., Bouma, T.J., Klassen, P., van der Wal, D., Stive, M.J.F., and Herman, P.M.J. 2010. Hydrodynamic forcing on salt-marsh development: distinguishing the relative importance of waves and tidal flows. Estuarine, Coastal and Shelf Science, 89, pp. 73-88. http://dx.doi. org/10.1016/j.ecss.2010.05.013

Carey, A.E. and Oliver, F.W. 1918. Tidal lands: a study of shore problems. Blackie \& Sons, $284 \mathrm{p}$.

Cecil, C. B. 2003. The concept of autocyclic and allocyclic 
controls on sedimentation and stratigraphy, emphasizing the climatic variable. In Climate Controls on Stratigraphy, SEPM Special Publication No. 77, pp. 13-20.

Chapman, V.J. 1960. Salt marshes and salt deserts of the World. Leonard Hill, London. Interscience, New York, $392 \mathrm{p}$.

Chauhan, P.P.S. 2009. Autocyclic erosion in tidal marshes. Geomorphology,110,pp.45-57.http://dx.doi.org/10.1016/ j.geomorph.2009.03.016

Dark, P. and Allen, J.R.L. 2005a. Pollen sources on a modern estuary salt marsh, and implications for the interpretation of Holocene estuarine pollen sequences. Archaeology in the Severn Estuary, 16, pp. 99-109.

Dark, P. and Allen, J.R.L. 2005b. Seasonal deposition of Holocene banded sediments in the Severn Estuary Levels (southwest Britain): palynological and sedimentological evidence. Quaternary Science Reviews, 24, pp. 11-33. http://dx.doi.org/10.1016/j.quascirev.2004.08.001

Fagherazzi, S., Kirwan, M.L., Mudd, S.M., Guntenspergen, G.R., Temmerman, S., D’Alpaos, A., van de Koppel, J., Rybczyk, J.M., Reyes, E., Craft, C., and Clough, J. 2012. Numerical models of salt marsh evolution: Ecological, geomorphic, and climatic factors. Reviews of Geophysics, 50, RG1002. http://dx.doi.org/10.1029/2011RG000359

Fagherazzi, S., Mariotti, G., Wiberg, P., and McGlathery, K. 2013. Marsh collapse does not require sea level rise. Oceanography, 26, pp. 70-77. http://dx.doi.org/10.5670/ oceanog.2013.47

Feagin, R. A., Lozada-Bernard, S.M., Ravens, T.M., Moeller, I., Yeager, K.M., and Baird, A.H. 2009. Does vegetation prevent wave erosion of salt marsh edges? Proceedings of the National Academy of Science, 106, pp. 10109-10113. http://dx.doi.org/10.1073/pnas.0901297106

French, J. 2006. Tidal marsh sedimentation and resilience to environmental change: exploratory modeling of tidal, sea-level and sediment supply forcing in predominantly allochthonous systems. Marine Geology, 235, pp. 119136. http://dx.doi.org/10.1016/j.margeo.2006.10.009

French, P.W. 1996. Implications of a salt marsh chronology for the Severn Estuary based on independent lines of dating evidence. Marine Geology, 135, pp. 115-125. http://dx.doi.org/10.1016/S0025-3227(96)00046-1

Friedrichs, C.T. and Perry, J.E. 2001. Tidal salt marsh morphodynamics: a synthesis. Journal of Coastal Research, Special Issue, 27, pp. 7-37.

Gao, S. and Collins, M. 1997. Formation of salt-marsh cliffs in an accretional environment, Christchurch Harbour, southern England. Proceedings of the Thirteeenth International Geological Congress, 13, pp. 95-110.

Greensmith, J.T. and Tucker, E.V. 1965. Saltmarsh erosion in Essex. Nature, 206, pp. 606-607. http://dx.doi. org/10.1038/206606a0

Harmsworth, G.C. and Long, S.P. 1986. An assessment of saltmarsh erosion in Essex, England, with reference to the
Dengie Peninsula. Biological Conservation, 35, pp. 377388. http://dx.doi.org/10.1016/0006-3207(86)90095-9

Haslett, S.K. 2006. Topographic variation of an estuarine salt marsh: Northwick Warth (Severn Estuary, UK). Occasional Papers in Geography, Bath Spa University, No. $3,17 \mathrm{p}$.

Haslett, S.K. 2008. Coastal systems. 2nd edition. Routledge, London, $240 \mathrm{p}$.

Haslett, S.K. 2011. Holocene sedimentation in a pericoastal river system (South Wales, UK): relationship to sea level, human activity, and coastal sediment flux. In Geoarchaeology, climate change, and sustainability. Edited by A.G. Brown, L.S. Basell, and K.W. Butzner. Geological Society of America, Special Paper, 476, pp. 93-103. http:// dx.doi.org/10.1130/2011.2476(08)

Haslett, S. K., Davies, P., and Strawbridge, F. 1998. Reconstructing Holocene sea-levels in the Severn Estuary and Somerset Levels: the foraminifera connection. Archaeology in the Severn Estuary, 8, pp. 29-40.

Jakobsen, J. 1954. The tidal area in south-western Jutland and the process of salt-marsh formation. Geografisk Tidsskrift, 53, pp. 49-61.

Jenkinson, A.F. and Collison, F.P. 1977. An initial climatology of gales over the North Sea. Memorandum No. 62, Meteorological Office. Bracknell, 18 p.

Jones, P.D., Hulme, M., and Briffa, K.R. 1993. A comparison of lamb circulation types with an objective classification. International Journal of Climatology, 123, pp. 655-663. http://dx.doi.org/10.1002/joc.3370130606

Kamphuis, J.W. 1987. Recession rate of glacial till bluffs. Journal of Waterway, Coastal and Harbour Engineering, 113, pp. 60-73.

Kelly, P.M., Jones, P., and Briffa, K. 1997. Classifying the winds and weather. In Climates of the British Isles: present, past and future. Edited by M. Hulme and E. Barrow. Routledge, London, pp. 153-169.

Kirwan, M.L. and Murray, A.B. 2005. Response of an ecomorphodynamic model of tidal marshes to varying sea level rise rates. In River, coastal and estuarine morphodynamics. Edited by G. Parker and M.H. Garcia. Taylor and Francis Group, London, pp. 629-634.

Kirwan, M.L. and Murray, A.B. 2007. A coupled geomorphic and ecological model of tidal marsh evolution. Proceedings of the National Academy of Sciences, 104, pp. 6118-6122. http://dx.doi.org/10.1073/pnas.0700958104

Lamb, H.H. 1972. British Isles weather types and a register of the daily sequence of circulation patterns, 1861-1971. Geophysical Memoir 116, HMSO, London, $85 \mathrm{p}$

Luternauer, J.L., Atkins, R.J., Moody, A.I., Williams, H.F.L., and Gibson, J.W. 1995. Salt marshes. In Geomorphology and sedimentology of estuaries. Edited by G.M.E. Perillo. Elsevier Science, pp. 307-332. http://dx.doi.org/10.1016/ S0070-4571(05)80031-7

Mariotti, G. and Fagherazzi, S. 2010. A numerical model 
for the coupled long-term evolution of salt marshes and tidal flats. Journal of Geophysical Research, 115, F01004. http://dx.doi.org/10.1029/2009JF001326

Mariotti, G. and Fagherazzi, S. 2013. Critical width of tidal flats triggers marsh collapse in the absence of sea-level rise. Proceedings of the National Academy of Science, 110, pp. 5353-5356. http://dx.doi.org/10.1073/pnas.1219600110

Ollerhead, J., Davidson-Arnott, R.G.D., and Scott, A. 2006. Cycles of salt marsh extension and contraction, Cumberland Basin, Bay of Fundy, Canada. In Geomorfologia littoral i Cuaternari: homenatge el Professor V.M. Rossello I Verger. Edited by E. Sanjaume and J.F. Mateu. Universidad de Valentia, pp. 293-306.

Pedersen, J.B.T. and Bartholdy, J. 2007. Exposed salt marsh morphodynamics: an example from the Danish Wadden Sea. Geomorphology, 90, pp. 115-125. http://dx.doi. org/10.1016/j.geomorph.2007.01.012

Pethick, J.S. 1981. Long-term accretion rates on tidal salt marshes. Journal of Sedimentary Petrology, 51, pp. 571577. http://dx.doi.org/10.1306/212F7CDE-2B24-11D78648000102C1865D

Pringle, A.W. 1995. Erosion of a cylic salt marsh in Morecambe Bay, north-west England. Earth Surface Processes and Landforms, 20, pp. 387-405. http://dx.doi. org/10.1002/esp.3290200502

Pye, K. 1995. Controls on long-term saltmarsh accretion and erosion in The Wash, eastern England. Journal of Coastal Research, 11, pp. 337-356.

Schwimmer, R.A. 2001. Rates and processes of marsh shoreline erosion in Rehoboth Bay, Delaware, U.S.A. Journal of Coastal Research, 17, pp. 672-683.

Smith, L.P. 1979. A survey of salt marshes in the Severn Estuary. Nature Conservancy Council., London, $100 \mathrm{p}$

Strawbridge, F., Haslett, S.K., Koh, A., Edwards, E., and Davies, C.F.C. 2000. The potential of aerial digital photography for saltmarsh monitoring. Occasional Papers in Geography, Bath Spa University College, No. 1, $15 p+4$ plates.

Temmerman, S., Govers, G., Wartel, S., and Meire, P. 2004. Modelling estuarine variations in tidal marsh sedimentation: response to changing sea level and suspended sediment concentration. Marine Geology, 212, pp. 1-19. http://dx.doi.org/10.1016/j.margeo.2004.10.021

Tonelli, M., Fagherazzi, S., and Petti, M. 2010. Modeling wave impact on salt marsh boundaries. Journal of Geophysical Research, 115, C09028. http://dx.doi. org/10.1029/2009JC006026

United Kingdom Hydrographic Office 2008. Admiralty tide tables. Volume 1, 2009, United Kingdom and Ireland. U.K. Hydrographic Office, 366 p.

van de Koppel, J., van der Wal, D., Bakker, J.P., and Herman, P.M.J. 2005. Self-organization and vegetation collapse in salt marsh ecosystems. The American Naturalist, 165, pp. E1-E12. http://dx.doi.org/10.1086/426602

van der Wal, D. and Pye, K. 2004. Patterns, rates and possible causes of saltmarsh erosion in the Great Thames area (UK). Geomorphology, 61, pp. 273-291. http://dx.doi. org/10.1016/j.geomorph.2004.02.005

van der Wal, D., Wielmarker-van den Dool, A., and Herman, P.M.J. 2008. Spatial patterns, rates and mechanisms of saltmarsh cycles (Westerschelde, The Netherlands). Estuarine, Coastal and Shelf Science, 76, pp. 357-368. http://dx.doi.org/10.1016/j.ecss.2007.07.017

Watson, E.B. 2008. Marsh-expansion at Calaveras Point Marsh, south San Francisco Bay, California. Estuarine, Coastal and Shelf Science, 78, pp. 593-602. http://dx.doi. org/10.1016/j.ecss.2008.02.008

Woodworth, P.L. 1990. A search for accelerations in records of European mean sea level. International Journal of Climatology, 10, pp. 128-143. http://dx.doi.org/10.1002/ joc.3370100203

Woodworth, P.L., Shaw, S.M., and Blackman, D.L. 1991. Secular trends in mean tidal range around the British Isles and along the adjacent European coastline. Geophysical Journal International, 104, pp. 593-609. http://dx.doi. org/10.1111/j.1365-246X.1991.tb05704.x

Woodworth, P.L., Tsimplis, M.N., Flather, R.A., and Shennan, I. 1999. A review of trends observed in British Isles sea level data measured by tide gauges. Geophysical Journal International, 136, pp. 651-670. http://dx.doi. org/10.1046/j.1365-246x.1999.00751.x

Yapp, R.H., Johns, D., and Jones, O.T. 1917. The salt marshes of the Dovey Estuary. Part II. The salt marshes. Journal of Ecology, 5, pp. 65-103. http://dx.doi.org/10.2307/2255644

Editorial responsibility: Robert A. Fensome 